\title{
Erik Bratland
}

Nord University, Nesna, Norway

e-mail: erik.bratland@nord.no

\section{Social realism and in-depth learning. Can students build knowledge with an epistemic dimension?}

\begin{abstract}
A mantra in today's technology-rich schools, with access to the internet and all sorts of information, is that students themselves should produce knowledge. In today's school, characterized by an unholy alliance between neo-liberal forces and constructivism, this requirement will most likely lead to a state in which knowledge is perceived as a form of social construction in a particular setting. This article raises several serious objections to such an approach, which reduces knowledge to knowing, which limits the scope for progression in the subject. This paper argues for a social and realistic alternative, formulated as knowledge building as theory development. Knowledge building as theory development exceeds the subjective doxa by linking knowledge with development of ideas and theories as the essential part of the students' creation of knowledge. Knowledge building as theory development opens up for students to build knowledge with an epistemic dimension, which is a prerequisite for in-depth learning in the school's subjects.
\end{abstract}

Keywords: social realism, in-depth learning, specialized knowledge, knowledge building as theory development, knowledge paradox, neoliberal school reforms

\section{Introduction}

The current neoliberal school reforms have strengthened the position of learning sciences and in particular of constructivism (Weelahan, 2010). 
In many cases, this development has gone hand in hand with stressing the importance of the so-called knowledge society, assuming that individuals need new forms of competences presented as 21st century skills (Ananiadou \& Claro, 2009). This development has led to the assumption that knowledge in education is what individuals can do and know, leading to what has been called a knowledge paradox (Bratland, 2016). Even though knowledge appears to be highly valued in the neoliberal school its meaning is identical with what has been learned, in other words, a mental condition of a knowing subject.

During the last ten years, a critique of the neoliberal school reforms, and in particular of the dethronement of knowledge, has been voiced by several educational sociologists (Moore 2004, Young 2008a, Weelahan 2010, Maton 2014). The learning sciences have gradually developed theories of how children and young adults learn, and it has been claimed that learning is ideally being created by building children and young adults' a priori knowledge (Sawyer, 2006); in practice, this is supposed to work best in learning by doing-situations. The strong position of learning sciences and constructivism in contemporary school has led to the view that knowledge in education is socially constructed without clear connection to establish knowledge about social and natural world. The knowledge that is learned in education, with and without the use of ICT, is constructed as "knowing", as a form of subjective knowledge that students acquire aided by specific pedagogical methods.

The alternative to constructivism's focus on social knowledge is a social and realistic theory about knowledge in education (Maton \& Moore, 2010). A central goal of this theory is to rehabilitate knowledge in school. The program for a new educational sociology was developed by Michael Young (2008a) in his landmark book: Bringing knowledge back in. The theory of social realism has grown and developed considerably, in particular through Karl Maton's $(2014,2016)$ Legitimation Code Theory (LCT) but still lacks a specific pedagogical theory and method for applying Young's motto in schools.

In-depth learning has been introduced as a core concept in the coming Norwegian school reform (LK20), with particular emphasis on the theories and concepts of the school subjects. Seen from a social and realistic perspective on knowledge, in-depth learning is a potential pathway to overcome the subjective doxa that today mark the learning processes 
in school, where knowledge is primarily understood as a social construction. With regard to the coming Norwegian school reform (LK 20), this article argues that in-depth learning can best be understood as knowledge building, with a focus on theory development in the classroom, where the aim is to create better explanations for phenomena in the social and natural world. Insight into scientific development and the relevance of theories and ideas for knowledge development has the potential to enable students to gain a deeper understanding of the world.

\section{Knowledge, in-depth learning, and the learning fallacy}

The concept in-depth learning originates in American cognitive research about children's learning. In-depth learning is a complex and compounded concept that refers to the idea that students in the contemporary world should not just learn a set of facts and procedures but should have "a deep conceptual understanding of complex concepts" (Sawyer, 2006, p. 2). The learning sciences have a developmental psychological approach to in-depth learning, examining how the understanding of children develops over time, and learning therefore should be based on earlier knowledge and experiences. This constructivist approach focuses on the cognitive development of children and young adults, guided by the main principle that school should build on a learner's prior knowledge (Sawyer, 2006, p. 2): "The best way for children to learn is in an environment that builds on their existing knowledge". This approach to in-depth learning is also known as student-centered perspective and aims at developing deep learning processes in school.

Seen from a social and realistic perspective, this constructivist approach, now dominant in schools (Weelahan, 2010), presents a profound problem with regard to knowledge. The learning sciences' strong focus on learning sees knowledge as a mental condition and it converts knowledge to knowing (Maton, 2014). Knowledge is not seen as a real and independent entity, with particular forms and inner structure, as something that has an impact on the world. In-depth learning, as the concept is used in the learning sciences, is not related to what Popper $(1972,1994)$ calls "objective knowledge". Instead, the term is linked to a subjective doxa (Maton 2014, p. 4), claiming that the development of new concepts and ideas works best when it builds on students' earlier acquired knowledge 
and experience. This approach, which is often associated with constructivism, implies that students' in-depth learning is generated in the form of constructing subjective knowledge without a clear connection to established forms of knowledge about the social and natural world. With this approach, in-depth learning does not present a solution but rather is a prolongation of the problem that there is too little focus on specialized knowledge in school. This problem, the assumption that one can learn about the world in an unmediated and direct way through practice and experience, can be called the learning fallacy (diSessa, 1993). From a constructivist point of view, knowledge is a social construction, and the construction is done by students who are situated in particular social practices in technology-rich environments in education.

The coming Norwegian school reform (LK 20) tried to solve the problem by linking in-depth learning to the theories and concepts of the subjects (Meld. St. 28, 2015-2016). The document defines in-depth learning in the following way: "In-depth learning means that students gradually develop their understanding of concepts and relationships within a subject" (p. 9). This definition separates in-depth learning from its base in students' earlier knowledge and experience as well as from the requirement to integrate new ideas and concepts into the established conceptual systems of the students. The emphasis on the subjects' own concepts indicates that knowledge must be understood as something more than a social construction. The acquisition of knowledge still has a social dimension, but the definition indicates a transformation of this dimension, linking students' understanding to subject-specific concepts and theories. While the learning sciences define in-depth learning as a process with a starting point in students' own experiences, where students gain a deeper understanding through social practices involving knowledge construction, the coming Norwegian curricular reform offers a different version: Knowledge is more than a mental condition-it is real and is expressed in the theories and concepts of the subjects. Students cannot construct knowledge arbitrarily and only investigate selected aspects of the world because knowledge construction should relies on established knowledge, which exists in the form of the concepts and theories of the subjects.

The analysis has so far illuminated the connection between in-depth learning and the concepts and theories of the subjects, thus preparing 
the ground for a new definition of knowledge in education. Stressing the importance of the subjects' concepts and theories does not imply a return to a one-sided cultivation of knowledge as being abstract and timeless, its structure unaffected by context. Instead, the point is that the theories and concepts of the subjects form part of established structures where knowledge assumes an objectified but nevertheless fallible form, influencing practices and knowledge building in the subjects. Below I will discuss the question of how the concepts and theories of the subjects can be linked to students' active construction of knowledge.

\section{Knowledge building as theory development in education}

It is a mantra of educational research that today's students, who have ample access to technology, should not just reproduce knowledge but also create it (Erstad 2010, Lund \& Hauge 2011). Examples of such activities are pedagogical methods that engage students in authentic and investigative practices, similar to what is used in research, including the use of technological tools. While this in principle can be fruitful, the prerequisite of this method is that students can rely on established knowledge, on theories and ideas, and are not restricted to subjective knowledge, acquired through specific activities, which have the aim to generate learning through finding the answer to given questions or the solution to problems. Well-known methods such as problem-based learning or investigative learning tend to be constructivist in their character and see knowledge as a mental state. The situation that knowledge is understood as knowing in education leads to several category mistakes. The first mistake, linked to an empirical version of knowing (Maton, 2014), is the idea that we learn about the world through direct experience or through empirical investigation rather than through established and objectified knowledge about the world. This approach, associated with problem-based and investigative methods, loses focus on concepts and theories, and it ignores the fact that practices for the creation of knowledge in education should not be divorced from established knowledge. Instead, it is a prerequisite for knowledge building as theory development that investigation results are related to the concepts and theories of the respective subjects. The 
second category mistake is the situated understanding of knowledge in education (Greeno, 2006). Here knowing is linked to context-dependent learning processes, often in the form of explorative learning (Furberg \& Lund, 2016), where the construction of the world is the result of collective work with the use of technology in the classroom. Of this approach there exist several variants, from purely student-driven group projects to activities where the teacher plays an active role, e.g. through asking students questions related to the respective topic. These approaches encompass topics in a subject field but treat the respective topic as a set of established facts, that are to be learned, and not as concepts that can be actively worked on, with ideas that can be evaluated and developed by students in the classroom.

The idea that established theories and concepts in the subjects can be elaborated and developed is still a rather foreign concept in education, but one should not forget that this is a common operation in research, where concepts and theories are understood as the raw materials of the subjects which can be used in new ways, depending on the character of the project, for example, through combining concepts from different theories or by giving concepts new meanings (Collier 1994, Bhaskar 1998). This operation, the adaptation and development of concepts is not just a creative exercise but aims at developing new research that can provide better explanations for events, phenomena, and situations with regard to the data that are collected in the project. This logic, where we creatively relate to established theories and concepts, involves a situation where we create knowledge that goes beyond our mental consciousness. With a starting point in creative elaboration and application of established theories and concepts, we create a result with a more objective character, providing not just opinions expressed in a particular context but ideas leading to new insights. In this way, we can develop and improve existing knowledge in both research and education, acquiring new insight and understanding through creative elaboration of established concepts and theories.

Creative theory development is the main ingredient in students' knowledge building, and it can inform the ambitions of social realism to a knowledge-building pedagogy. Such approaches are found in the contributions of Young (2008a), Wheelahan (2010), but also in Maton's LCT-theory $(2014,2016)$, with its emphasis on diverse knowledge practices enacted in the classroom. Maton (2014, p. 108) distinguishes in 
this context between segmental and cumulative forms of knowledge building, where only the latter has a context-exceeding character. For a social and realist pedagogical theory, however, it is not sufficient to have insight into underlying principles. Instead, a theory must be translated into practices, implying a knowledge building that provides children and young adults with a deeper understanding of the world. Weelahan (2010, p. 7) argues that students need access to theoretical knowledge, "so that they can navigate the boundaries between theoretical and practical knowledge and between different kinds of knowledge." In this way, students gain insight into the specialized practices that are the basis for the production of knowledge in the different disciplines. According to Young (2008b, p. 14), "[p]owerful knowledge provides more reliable explanations and new ways of thinking about the world and acquiring it can provide learners with a language for engaging in political, moral and other kinds of debates." Weelahan (2010, p. 85) further argues that a curriculum that emphasizes knowledge of the disciplines should have truth as a "normative goal", but that this goal should be modulated in the face of the fallibility of knowledge and the need for revision in the case of new results. Weelahan (2010) argues that such a version of knowledge building provides students with tools to test knowledge and to evaluate different theories and explanations while considering alternative ways of thinking.

There are several approaches that promote creative theory development (DiSessa 2000, Wilensky \& Reisman 2006, Lipman 1988, Bereiter \& Scardamalia 2010). Bereiter \& Scardamalia's theory about knowledge building combines a focus on students as producers of ideas and on the elaboration and development of these ideas and theories. Here the students' theory development in the classroom, also described as conceptual artifacts, originates in the principle of "constructive use of authoritative sources" (Bereiter \& Scardamalia, 2010, p. 12). This principle makes it possible to link the students' ideas to concepts and theories with the aim is to foster students' theory development in the classroom. Even though knowledge building and theory development in the classroom are inspired by science, theory development in the classroom has a different character that in several points is distinguished from both researches' work routines and from progress in the scientific subjects. Students in school lack the overview of the fields of research, and they will not have 
thorough knowledge of established theories as well as the systematic studies they are based upon. Arguably, the most profound difference is that the aim of theory development in the classroom is to gain a deeper understanding, not to engage in scientific development. The assumption here is that teaching with a focus on theory development can lead students to a different and deeper understanding of knowledge transgressing the subjective doxa that dominate the methods in contemporary school.

\section{A pedagogical theory of knowledge building}

The Canadian researchers Scardamalia and Bereiter $(2006,2014)$ have been in the forefront developing a pedagogical theory of knowledge building in education. Their theory combines constructivism with Popper's three worlds theory (1972) and places the students' knowledge building into the center of education. Knowledge creation is nevertheless not understood in a constructivist manner as in Piaget but as a kind of productive work "that goes on in research and engineering laboratories, in creative scholarship, and in innovative groups of all sorts" (Bereiter \& Scardamalia, 2010, p. 2). In research, in particular if conducted in the spirit of Popper, knowledge is generated through the testing of hypotheses and the development of theories. The pedagogical theory of knowledge building is in a similar way focused on "real ideas" that address "real problems" clearing the way for further theory development, where students can acquire a deeper understanding of knowledge in education.

According to Chey et al. (2010, p. 5-6), students particularly need to understand three problems that are prerequisites for theory development in the classroom and that can provide better explanations of the natural and social world. These problems are related to different levels forming scientific literacy. The levels or problems are as follows:

1. The differentiation between theories and facts. Theories are not facts; theories explain facts.

2. The development of theories depends on an evaluation of their explanatory strength. Some theories are better than other theories because they explain the facts better, explain more facts, etc.

3. Explanations are linked to ideas. Ideas form the core of each theory. Ideas are decisive for new discoveries and for creating new knowledge. 
It is challenging to develop an understanding of these problems, but a pedagogical approach to knowledge building implies that students should be engaged in these problems in order to develop the process of generating ideas and developing theories in the classroom. To succeed in this task, students need at least to understand levels 1 and 2. As mentioned, knowledge building in the classroom will not fully manage to meet the demands of theory development in science, but Bereiter and Scardamalia (2010, p. 7) argue that students can build quasi-theories: "Typically their creations fall short of yielding testable predictions, but good student-generated theories are vulnerable to evidence, improvable and discussable in terms of what they explain and fail to explain." Student theories are different from scientific ones since the latter ones have the aim to solve problems of understanding; however, they can still meet the requirement of "explanatory coherence" (Thagard, 2000), a standard that includes requirements of internal coherence, coherence with accepted facts, and coherence with other theories. The last requirement is particularly important in the natural sciences; however, knowledge building as theory development in education is not limited to the natural sciences but encompasses subject areas that typically are marked by more particular theories such as social sciences and some of the humanist subjects.

Knowledge building as theory development in the classroom can provide students with a deeper understanding and has several advantages over traditional classroom teaching. To investigate whether knowledge building really leads to a deeper understanding, a development of the students' understanding of natural science and scientific development, Chuy and her colleagues conducted a groundbreaking study of primary school students (Chuy et al., 2010). The study was designed as a "natural experiment", where two different approaches -knowledge building and explorative learning - were used in two different school classes. The two classes followed the same curriculum and studied the same topics and content (light and energy). The participants were nine and ten-year-old girls from two fourth grade classes in Canada, and all participants experienced the respective pedagogical approaches for at least four months. In the experimental class, the approach of knowledge building was conducted according to Scardamalia and Bereiter's $(2006,2010)$ principles. The knowledge building approach was realized by the class using Knowledge Forum, a data program for developing theories and 
working creatively with ideas. The program supports students through providing categories (My theory, I need to understand, New information, This theory cannot explain, A better theory, Evidence, Putting our knowledge together), stimulating students' theory development in the classroom. In the other class, a project based and constructivist approach to exploration was used. Here the collaborative projects, which were conducted over a longer period of time, had the aim to answer the students' own questions. The teacher encouraged students to use technological and other sources to investigate and to express their ideas. Projects and their outcomes were expressed in a number of multimodal formats such as music, images, sculptures, and performance, understood as tools for exploration, problem solving, and thinking.

To investigate the degree of understanding or in-depth learning, all participants were interviewed twice: All students were interviewed individually at the onset of the study and again after four months. The questions were designed for mapping the students' understanding of scientific studies, theoretical development, and the relation between ideas and facts. Data were compared and analyzed according to a set of categories, related to the mentioned problems of understanding: Nature of theoretical progress, theory-fact understanding, role of ideas in scientific inquiry, invention. Not unexpectedly, the study confirmed that the general understanding of scientific development and knowledge, described as scientific literacy, was significantly higher in the knowledge building class, compared with the students in the control group. The authors of the study explain this difference and conclude (Chuy et al., 2010, p. 17):

Thus we are left with technologically supported Knowledge Building as the most plausible explanation of the higher levels of scientific literacy shown by the experimental group. With extended immersion in a Knowledge building environment, nine and ten year old girls were able to understand that the goal of science is to improve available explanations of phenomena, rather than accumulate a certain number of facts.

Knowledge building with a focus on ideas rather than on fact or activities enabled students to understand why theories are so important for scientific development. Knowledge building as theory development allowed students to transgress traditional school learning and enabled students to construct a deeper understanding of phenomena in nature. Thus, education turned into something more than learning a set of facts, 
and students became agents in a process of discovery, driven by themselves. Knowledge building with theory development enabled students to process knowledge as something real and objective, marked by a potential for development, being more than a social construction in particular contexts.

\section{Conclusion}

The social and realistic theory of knowledge argues that knowledge in education cannot be reduced to being a social construction, emerging from learning in a particular setting. (Maton \& Moore 2010, Maton 2014). While knowledge has a social character, it is also real. The social and natural worlds have their own structures, which are expressed through established knowledge abouth the world. Established knowledge is fallible and can be improved and changed through testing, modification, and the development of theories providing continuously improving explanations of phenomena in the social and natural world. The development of theories and concepts, which form the base of our established knowledge is a cardinal principle of pedagogical theory of knowledge building in education (Young, 2008b), a principle aimed at overcoming segmentalism with its learning of local and strongly context-determined knowledge in education.

An often-heard mantra in Norwegian schools is that with rich access to technology, internet, and information the students themselves can become producers, not just consumers of knowledge (Lund \& Hauge, 2011). While the implications of this message may be vague, there are many reasons to assume, in a school characterized by a subjective doxa, that this mantra will likely result in a constructivist approach, the idea that knowledge is socially constructed in a particular setting. This article has raised several grave objections against such an approach, against the reduction of knowledge to knowing. This approach leads to learning, but not necessarily to the learning of specialized knowledge in school. Knowledge building as theory development is a far more promising approach because it links knowledge with the development of ideas and theories, allowing them to form an essential part of students' creation of knowledge. The coming Norwegian school reform (LK 20), which connects in-depth learning with the subject's concepts and theories may be 
able to strengthen knowledge building as a good pedagogical alternative in school.

The social and realistic theory argues that the aim of education is to provide students with access to specialized knowledge. This raises the question to which degree students' knowledge building lives up to this idea: Can students build knowledge that is not merely social but has an epistemic dimension? The answer to this question will depend on which criteria are used when students build knowledge in education. Bereiter and Scardamalia (2010) point out that students' knowledge building aims lead to a deeper understanding of the world. Therefore, knowledge building as theory development in education should be conducted differently from knowledge building in research. Even though there are similarities between knowledge building in research and education, the students' theory development cannot fully meet the demands that are made in research. However, in contrast to ordinary learning activities, students' knowledge building will be in accordance with some central principles for knowledge development; the students' idea development takes the form of a constructive use of authoritative sources, and it addresses real problems in the social and natural world.

Knowledge building go beyond the confines of school's subjective doxa by treating knowledge as something real and objectified and by framing the students' building of knowledge, thus safeguarding that students' knowledge will contain an epistemic relation to knowledge. There is reason to believe that the strength of epistemic relations will vary because of the different forms of knowledge in the subjects and different forms of knowledge practices in the classroom. Which forms of knowledge practices can best support epistemic relations is a topic for further research. The focus on knowledge building as theory development, with the goal to find better explanations of facts, can be seen as a suitable starting point. As the above-mentioned study shows, in comparison with traditional pedagogical methods, knowledge building provides a deeper understanding of the world by developing a certain scientific literacy (Chuy et al., 2010). The students in the study are able to distinguish between facts and theories, and it shows that girls as young as ten are capable to develop theories that explain selected aspects of the natural world. Not the least, the study shows that students in school can 
themselves construct knowledge in a particular setting without reducing knowledge to knowing.

\section{References}

Bereiter C. \& Scardamalia M. (2010), Can Children Really Create Knowledge?, "Canadian Journal of Learning and Technology", 36(1).

Bhaskar R. (1998), The possibility of naturalism: a philosophical critique of the contemporary human sciences (3rd ed. ed.), London: Routledge.

Bratland E. (2016), Reform, competence and knowledge: paradoxes of knowledge in the neoliberal transformation of education [in:] E. Bratland, Sieminiecka, D. \& Siemieniecki, B. (Ed.), Knowledge, ICT and education - a variety of perspectives (pp. 117-132). Toruń: Adam Marszałek.

Chuy M. et al. (2010), Understanding the Nature of Science and Scientific Progress: A Theory-Building Approach, "Canadian Journal of Learning and Technology", 36(1), doi:10.21432/T2GP4R

Collier A. (1994), Critical realism: an introduction to Roy Bhaskar's philosophy, London: Verso.

Disessa A. A. (1993), Toward an Epistemology of Physics, "Cognition and Instruction”, 10(2-3), p. 105-225. doi:10.1080/07370008.1985.9649008.

DiSessa A. A. (2000), Changing minds: Computers, learning, and literacy. Cambridge: The MIT Press.

Erstad O. (2010), Kunnskapsbygging i kulturhistorisk perspektiv - materialitet, mediering og utforskende arbeidsmåter Kunnskap i skolen, Trondheim: Tapir akademisk, pp. 113-114.

Furberg A. \& Lund A. (2016), En profesjonsfaglig digitalt kompetent lærer? Muligheter og utfordringer i teknologirike læringsomgivelser [in:] R. J. Krumsvik (Ed.), Digital læring i skole oglærerutdanning (2. utg. ed., pp. 26-48). Oslo: Universitetsforlaget.

Greeno G. J. (2006), Learning in activity [in:] R. K. Sawyer (Ed.), The Cambridge handbook of the learning sciences, Cambridge Cambridge University Press, pp. 79-96.

Lipman M. (1988), Philosophy goes to school, Philadelphia: Temple University Press.

Lund A. \& Hauge T. E. (2011), Designs for teaching and learning in technology-rich learning environments, "Nordic journal of digital literacy" (4), p. 258-272. 
Maton K. (2014), Knowledge and knowers: towards a realist sociology of education, New York: Routledge.

Maton K. \& Hood S. \& Shay S. (2016), Knowledge-building: educational studies in legitimation code theory, Routledge, Taylor \& Francis Group.

Maton K. \& Moore R. (2010), Social realism, knowledge and the sociology of education: coalitions of the mind, London: Continuum.

Meld. St. 28, 2015-2016. Fag - fordypning - forståelse: en fornyelse av Kunnskapsløftet, Oslo: Kunnskapsdepartementet.

Moore R. (2004), Education and society: issues and explanations in the sociology of education, Cambridge: Polity.

Popper K. R. (1972), Objective knowledge: an evolutionary approach, Oxford: Clarendon Press.

Popper K. R. \& Notturno M. A. (1994), Knowledge and the body-mind problem: in defence of interaction, London: Routledge.

Sawyer R. K. (2006), The Cambridge handbook of the learning sciences, Cambridge: Cambridge University Press.

Scardamalia M. \& Bereiter C. (2006), Knowledge building: theory, pedagogy and tecnology [in:] R. K. Sawyer (Ed.), The Cambridge handbook of the learning sciences, Cambridge: Cambridge University Press, pp. 97-115.

Statsministerens kontor (2018), Retningslinjer for utforming av nasjonale og samiske læreplaner for fag i LK20 og LK20S, Oslo: Kunnskapsdepartementet.

Thagard P. (2000), Coherence in thought and action, Cambridge, Mass: MIT Press. Wheelahan L. (2010), Why knowledge matters in curriculum: a social realist argument, London: Routledge.

Wilensky U. \& Reisman K. (2006), Thinking Like a Wolf, a Sheep, or a Firefly: Learning Biology Through Constructing and Testing Computational Theories - An Embodied Modeling Approach, "Cognition and Instruction", 24(2), p. 171-209, doi:10.1207/s1532690xci2402_1

Young M. F. D. (2008a), Bringing knowledge back in: from social constructivism to social realism in the sociology of education, London: Routledge.

Young M. (2008b), From Constructivism to Realism in the Sociology of the Curriculum, "Theory and Research in Education", 5, (2), p. 173-201. 